Revue d'histoire de l'Amérique française

REVUE D.HISTOIRE DE L'AMÉRIQUE FRANÇAISE

\title{
SÉGUIN, Maurice, Une histoire du Québec. Vision d'un prophète (Montréal, Guérin éditeur, 1995).
}

\section{Jean Lamarre}

Volume 50, numéro 2, automne 1996

URI : https://id.erudit.org/iderudit/305551ar

DOI : https://doi.org/10.7202/305551ar

Aller au sommaire du numéro

Éditeur(s)

Institut d'histoire de l'Amérique française

ISSN

0035-2357 (imprimé)

1492-1383 (numérique)

Découvrir la revue

Citer ce compte rendu

Lamarre, J. (1996). Compte rendu de [SÉGUIN, Maurice, Une histoire du Québec.

Vision d'un prophète (Montréal, Guérin éditeur, 1995).] Revue d'histoire de

l'Amérique française, 50(2), 324-324. https://doi.org/10.7202/305551ar d'utilisation que vous pouvez consulter en ligne.

https://apropos.erudit.org/fr/usagers/politique-dutilisation/ 
SÉGUIN, Maurice, Une histoire du Québec. Vision d'un prophète (Montréal, Guérin éditeur, 1995).

La réédition de ce livre de Maurice Séguin se faisait attendre. Il constitue, au sens fort du terme, une histoire nationale qui ne s'embourbe point dans les myriades de faits secondaires pour se concentrer sur les faits de structure clés. En fait, cette histoire du Québec s'articule sur deux plans complémentaires. D'une part, elle porte attention aux principales réalités que sont le politique, l'économique et le culturel, réalités sans lesquelles une nation et le nationalisme qu'elle pratique ne sauraient être appréhendés comme une totalité. D'autre part, elle retrace comment la Conquête et le remplacement d'une source de colonisation par une autre ont induit un processus de déstructuration et de restructuration qui a fait du Québec une nation «annexée» à une autre au sein de la Confédération. Pour Séguin, tout s'est joué entre 1760 et 1867 . Car c'est justement au moment où s'opère le renversement démographique et l'annexion politique du Québec - et que l'infériorité économique des Québécois est mise en relief avec les débuts de l'industrialisation - que les Québécois commencent à pratiquer un nationalisme culturel en s'imaginant qu'ils ont non seulement une vocation agricole, mais qu'ils sont les égaux de leurs conquérants: c'est ce phénomène d'aliénation collective qui apparaît à Séguin comme l'indice complémentaire que la partie est définitivement jouée. Depuis ce temps, le Québec n'aurait fait que se débattre dans les fils de la conjoncture en poursuivant sa course au creux de la trajectoire que lui ont imprimé les principales solutions mises en place au milieu du $\mathrm{XIX}^{\mathrm{e}}$ siècle pour résoudre le problème de la coexistence de deux nations.

Après avoir lu cette Histoire du Québec, le lecteur profitera d'un promontoire d'où il sera plus à même d'évaluer le lien dynamique qui unit le passé au présent. 